Anna PotyraŁA

Uniwersytet im. Adama Mickiewicza, Poznań

\title{
Unia Europejska wobec nowych tworów państwowych (Casus Kosowa, Abchazji i Osetii Południowej)
}

\author{
[...] Unia Europejska [...] \\ musi być w stanie gwarantować stabilność, \\ zapobiegać konfliktom i zarzqdzać kryzysami \\ u swoich granic \\ Komunikat Komisji Europejskiej \\ „Budowanie naszej wspólnej przyszłości: \\ polityczne wyzwania i środki budżetowe powiększo- \\ nej Unii 2007-2013”, 26 lutego 2004
}

Z adając pytanie o przyszłość Unii Europejskiej i jej międzynarodowe znaczenie na jeden z pierwszych planów wysuwa się problematyczna kwestia nowych organizmów państwowych, wobec niepodległości których Unia Europejska nie jest w stanie przyjąć jednolitego stanowiska. Działając w określonej przestrzeni międzynarodowej, dążąc do odgrywania pierwszoplanowej roli na kontynencie, Unia Europejska nie jest zdolna do wypracowania formuły pozwalającej na pogodzenie niepodległościowych dążeń z koniecznością zagwarantowania suwerennych praw państw. Tymczasem od stanowiska w sprawie nowych państw uzależniona jest nie tylko pozycja Unii Europejskiej na arenie międzynarodowej, ale również dynamiczna, skuteczna i pokojowa współpraca europejska.

Ogłoszenie niepodległości przez Kosowo w lutym 2008 roku doprowadziło do rozłamu wśród państw członkowskich UE, z których część optowała za uznaniem nowego państwa, inne zaś sprzeciwiały się uznaniu w obawie przed nasileniem niepodległościowych dążeń w innych częściach kontynentu. Obawy te okazały się zasadne, gdy w połowie 2008 roku władze Rosji dokonały uznania Abchazji i Osetii Południowej. Uwzględniając brak porozumienia państw członkowskich w sprawie uznania Kosowa, 18 lutego 2008 roku Rada w przyjętych konkluzjach wskazała, iż „państwa członkowskie zdecydują zgodnie z narodową praktyką i prawem międzynarodowym, o swoich relacjach z Kosowem”. 
Pomimo, iż uznanie nie tworzy nowej sytuacji prawnej i nie jest warunkiem państwowości ${ }^{1}$, nowo tworzone państwa zabiegają o międzynarodowe uznanie. Od uznania bowiem uzależnione jest rzeczywiste funkcjonowanie państwa na arenie międzynarodowej. Bez uznania ze strony innych państw byt państwowy pozostaje 'nie-bytem' (ang. non- entity $)^{2}$. „Państwo, które nie zostało uznane, albo które uzyskało uznanie tylko ze strony ograniczonej liczby państw, z trudnością realizuje niektóre uprawnienia przysługujące mu na podstawie prawa międzynarodowego [...] nie bierze udziału w życiu międzynarodowym albo czyni to w ograniczonym stopniu" "3. Państwo, które nie uzyskało uznania międzynarodowego nie może w pełni realizować na przykład możliwości uczestniczenia w organizacjach międzynarodowych (przypadek Republiki Chińskiej na Tajwanie, która od wielu lat zabiega o członkostwo w Organizacji Narodów Zjednoczonych), zdolności traktatowej (odmawiano jej na przykład Republice Chińskiej na Tajwanie oraz Korei Południowej, a złożenie podpisów w roku 1970 przez przedstawicieli tych państw pod Konwencją o prawie traktatów spotkało się z natychmiastowymi protestami państw bloku wschodniego), prawa legacji i konsulatu, czy przywilejów i immunitetów dla przedstawicieli państwa. $Z$ tego względu niezbędne stało się określenie warunków, od spełnienia których uzależnia się dokonanie uznania państwa. Po raz pierwszy warunki dokonania uznania państwa określone zostały w 1825 roku przez ówczesnego ministra spraw zagranicznych Wielkiej Brytanii Canninga. Na uznanie mogło liczyć jedynie państwo, którego rząd notyfikował niepodległość nowego tworu państwowego, sprawował rzeczywistą władzę w państwie, cechował się stabilnością i jednolitością, a także zakazał handlu niewolnikami ${ }^{4}$.

$\mathrm{Z}$ uwagi na zmiany terytorialne, do których doszło w Europie po 1989 roku oraz konieczność ujednolicenia kryteriów uznania i ich dostosowania do współczesności, 16 grudnia 1991 roku ministrowie spraw zagra-

1 Por. Artykuł 3, Konwencja o prawach i obowiazkach państw, Montevideo 1933, w: S. Sierpowski, Źródła do historii powszechnej okresu międzywojennego, tom drugi: 1927-1934, Poznań 1992.

2 R. D. Sloane, The Changing Face of Recognition in International Law: A Case Study of Tibet, „Emory International Law Review” 2002, vol. 16, s. 116.

Zarys prawa międzynarodowego, t. II, red. M. Muszkat, Warszawa 1956, s. 6.

${ }^{4}$ R. Bierzanek, J. Symonides, Prawo międzynarodowe publiczne, Warszawa 1994, s. 134. 
nicznych państw członkowskich Wspólnot Europejskich, podczas spotkania w Brukseli przyjęli Deklarację w sprawie uznania nowych państw, powstałych w Europie Wschodniej i na obszarze Związku Radzieckiego. W Deklaracji wskazano warunki, jakie muszą być spełnione, aby państwo uzyskało międzynarodowe uznanie. Zaliczono do nich obowiązek:

- poszanowania postanowień Karty Narodów Zjednoczonych, Aktu Końcowego KBWE oraz Paryskiej Karty Nowej Europy;

- zagwarantowania praw mniejszości narodowych, etnicznych, zgodnie ze zobowiązaniami wynikającymi z ustaleń ówczesnej KBWE;

- zagwarantowania zasady nienaruszalności granic, które mogą być zmienione jedynie na mocy wspólnych porozumień wypracowanych metodami pokojowymi;

- przyjęcia rozwiązań zobowiązujących do rozbrojenia, nierozprzestrzeniania broni jądrowej oraz przyjęcia układów w sprawie stabilizacji i bezpieczeństwa regionalnego;

- poszanowania zasady nakazującej pokojowe rozwiązywanie sporów, z uwzględnieniem sporów dotyczących sukcesji ${ }^{5}$.

Przedstawiciele państw członkowskich Wspólnot podkreślili także, iż nie będą uznawać tworów powstałych w rezultacie agresji oraz że przed podjęciem ostatecznej decyzji w sprawie uznania uwzględnione zostaną następstwa, z jakimi zetkną się państwa sąsiednie. Kryteria te odzwierciedlają nie tylko zasady prawa międzynarodowego (obowiązek pokojowego rozwiązywania sporów międzynarodowych, zasada nienaruszalności granic), leżące u podstaw porządku międzynarodowego, ale również normy ius cogens (ochrona praw człowieka, poszanowanie zasady suwerennej równości państw, zakaz użycia siły i groźby użycia siły $)^{6}$.

Pomimo wypracowania kryteriów uznania nowych państw, nadal trudno jednoznacznie stwierdzić czy dokonane zmiany terytorialne są zgodne z obowiązującymi normami prawnymi. Na szali kładzie się dwie zasady prawa międzynarodowego: suwerenność państwa i samostanowienie na-

5 Declaration on the Guidelines on the Recognition of the New States in Eastern Europe and in the Soviet Union, http://europa.eu. Patrz też: Zalecenia co do uznawania nowych państw w Europie Wschodniej oraz ZSRR, przyjęte przez Wspólnotę Europejskq oraz jej członków w dniu 16 XII 1991, w: Prawo międzynarodowe. Materiaty do studiów, red. B. Wierzbicki, Białystok 2000, s. 307-308.

${ }^{6}$ Nie ma racji Ch. Hillgruber, który zaprzecza związkowi kryteriów opracowanych w ramach Wspólnot Europejskich z zasadami prawa międzynarodowego. Patrz: Ch. Hillgruber, The Admission of New States to International Community, „European Journal of International Law" 1998, vol. 9, s. 492-493. 
rodów. Społeczność międzynarodowa, przynajmniej w sferze deklaratoryjnej, dopuszcza możliwość uznania państwa powstałego wyłącznie na drodze pokojowej. W latach sześćdziesiątych XX wieku powszechnie akceptowano państwa powstałe w wyniku dekolonizacji. Współcześnie, nie budzi wątpliwości uznanie następujące w odpowiedzi na decyzję społeczności zamieszkującej dane terytorium, wyrażoną w drodze referendum niepodległościowego, jak stało się w przypadku Timoru Wschodniego. W praktyce jednak, o tym, które państwo czy terytorium na szanse uzyskać uznanie międzynarodowe decydują przede wszystkim względy polityczne. Uznanie państwa nie jest bowiem kwestią uzależnioną od prawa, lecz polityki ${ }^{7}$. Jak bardzo, widać wyraźnie w przypadku Kosowa, Abchazji i Osetii Południowej.

\section{Unia Europejska wobec niepodległości Kosowa}

Po wydarzeniach z 1999 roku, zgodnie z rezolucją Rady Bezpieczeństwa ONZ nr 1244 z 10 czerwca 1999 roku, Kosowo objęte zostało międzynarodową kontrolą. Jego status miał zostać określony drogą porozumienia władz serbskich i kosowskich. 26 marca 2007 roku Rada Bezpieczeństwa ONZ zapoznała się z propozycją statusu Kosowa, zaprezentowaną przez Marttiego Ahtisaariego. Plan zakładał niepodległość Kosowa, przy jednoczesnym utrzymaniu międzynarodowej kontroli. Z uwagi na brak porozumienia państw zasiadających w Radzie Bezpieczeństwa, propozycja nie została przyjęta. Korzystając jednak z przychylności Stanów Zjednoczonych i większości członków Unii Europejskiej (plan M. Ahtisaariego został zaakceptowany przez Parlament Europejski), 17 lutego 2008 roku władze Kosowa proklamowały niepodległość „,W odpowiedzi na wezwanie narodu do zbudowania społeczeństwa, które szanuje ludzką godność" i w celu ,zapewnienia narodowi pewności przyszłości”. Zadeklarowano, że Kosowo będzie państwem „demokratycznym, świeckim i wieloetnicznym", hołdującym zasadzie niedyskryminacji i równej ochrony prawnej, przestrzegającym praw mniejszości ${ }^{8}$.

7 Porównaj: R. Rich, Recognition of States: the Collapse of Yugoslavia and the Soviet Union, „European Journal of International Law” 1993, vol. 4, no. 1, s. 36.

8 Preambuła i punkt 2, Kosovo declaration of independence, signed in parliament by Speaker Jakup Krasniqi, Prime Minister Hashim Tkaci and President Fatmir Sejdi, Pristina 17.02.2008. 
Do końca lutego 2010 roku Kosowo zostało uznane przez 65 państw, w tym przez 22 państwa członkowskie Unii Europejskiej (patrz: tabela 1). Zwolennicy niepodległości Kosowa powołali się na postanowienia wspomnianej wyżej rezolucji nr 1244, na mocy której ówczesna Federalna Republika Jugosławii zobowiązana została do wycofania wojsk z Kosowa i przekazania kontroli nad prowincją Narodom Zjednoczonym. W rezolucji nie wskazano, iż międzynarodowy nadzór jest pierwszym krokiem ku niepodległości, jednak biorąc pod uwagę niedawne doświadczenia Timoru Wschodniego, przyjać można, że droga ku niepodległości jest w takim przypadku otwarta. Istotne znaczenie ma bowiem wola mieszkańców oraz stworzenie zdolnych do samodzielnego rządzenia organów władzy. Państwa, które opowiedziały się za uznaniem Kosowa wskazywały, że deklaracja niepodległości była konsekwencją porażki wysiłków społeczności międzynarodowej na rzecz wypracowania porozumienia między władzami Serbii i Kosowa. „W takiej sytuacji zmiana statusu Kosowa była nieunikniona"9.

Tabela 1

Państwa czlonkowskie UE, które dokonały uznania Kosowa (stan na luty 2010)

\begin{tabular}{||l|c|l||}
\hline \multicolumn{1}{|c|}{ Państwo } & $\begin{array}{c}\text { Data dokonania } \\
\text { uznania }\end{array}$ & \multicolumn{1}{|c||}{ Organ uprawniony do podjęcia decyzji } \\
\hline \multicolumn{1}{|c||}{1} & \multicolumn{1}{|c||}{3} \\
\hline Francja & 18.02 .2008 & Rząd \\
\hline Wielka Brytania & 18.02 .2008 & Rząd we współpracy z parlamentem \\
\hline Lotwa & 20.02 .2008 & \\
\hline Niemcy & 20.02 .2008 & Rząd federalny \\
\hline Dania & 21.02 .2008 & Rząd \\
\hline Estonia & 21.02 .2008 & Rząd \\
\hline Luksemburg & 21.02 .2008 & Rząd we współpracy z parlamentem \\
\hline Włochy & 21.02 .2008 & Rząd we współpracy z parlamentem \\
\hline Belgia & 24.02 .2008 & Minister spraw zagranicznych \\
\hline Polska & 26.02 .2008 & Rada Ministrów \\
\hline Austria & 28.02 .2008 & Rząd \\
\hline Irlandia & 29.02 .2008 & Rząd \\
\hline
\end{tabular}

9 Joint Statement of Bulgaria, Hungary and Croatia on forthcoming recognition of Kosovo, 19.03.2008, http://www.mfa.gov.hu (16.09.2008). 


\begin{tabular}{||l|c|l||}
\hline \multicolumn{1}{|c|}{1} & \multicolumn{1}{|c||}{3} \\
\hline Holandia & 4.03 .2008 & Rząd \\
\hline Szwecja & 4.03 .2008 & Rząd wspólnie z Radą Doradczą ds. zagranicznych \\
\hline Słowenia & 5.03 .2008 & Rząd we współpracy z parlamentem \\
\hline Finlandia & 7.03 .2008 & Prezydent we współpracy z rządem \\
\hline Węgry & 19.03 .2008 & Rząd \\
\hline Bułgaria & 20.03 .2008 & \\
\hline Litwa & 6.05 .2008 & Parlament \\
\hline Republika Czeska & 21.05 .2008 & Prezydent \\
\hline Malta & 21.08 .2008 & Parlament \\
\hline Portugalia & 7.10 .2008 & Rząd \\
\hline
\end{tabular}

Źródło: Opracowanie własne na podstawie The role of parliaments in the recognition of Kosovo. Report submitted on behalf of the Parliamentary and Public Relations Committee, A/2023, Rome 3.12.2008; oraz UN on Kosovo independence, http://www.un.org/english (28.02.2010).

Z drugiej strony, rządy Hiszpanii, Cypru, Słowacji, Rumunii i Grecji odmówiły uznania Kosowa, obawiając się, że może ono stanowić precedens i prowadzić do nasilenia separatystycznych dążeń w Abchazji, Południowej Osetii, Górnym Karabachu, Republice Naddniestrzańskiej, Republice Serbskiej w Bośni i Hercegowinie, Kraju Basków, Szkocji czy na Korsyce. Ze strony tych państw padły również argumenty prawne, oparte o zapisy rezolucji nr 1244 (artykuł 10 wskazuje na autonomię Kosowa w ramach ówczesnej Republiki Jugosławii) oraz postanowienia Karty Narodów Zjednoczonych czy Deklaracji Zasad Prawa Międzynarodowego. 12 lutego 2008 roku Sergiej Ławrow, stwierdził, że uznanie niepodległości Kosowa traktować należy jako naruszenie podwalin prawa międzynarodowego, a zmiana granic w Europie może być dokonana wyłącznie na podstawie umowy międzynarodowej. Skoro brak takiego porozumienia, uznanie niepodległości Kosowa jest przedwczesne. Minister do spraw europejskich Hiszpanii, Alberto Navarro podkreślił, że „wiele osób ma wątpliwości czy to co się dzieje jest legalne z punktu widzenia prawa międzynarodowego", zaś minister spraw zagranicznych Miguel Angel Moratinos stwierdził, że Hiszpania nie dokona uznania Kosowa, gdyż „nie uznaje deklaracji niepodległości za zgodną z prawem międzynarodowym" $"$.

10 BBC Press Release, 18.02.2008; oraz The role of parliaments in the recognition of Kosovo. Report submitted on behalf of the Parliamentary and Public Relations Committee, A/2023, Rome 3.12.2008, s. 19. Sprzeciw wobec uznania Kosowa wyra- 
Krytykując decyzję o uznaniu, podjętą przez 22 państwa członkowskie Unii Europejskiej, minister spraw wewnętrznych Serbii złożył doniesienie o popełnieniu przestępstwa przez przywódców kosowskich Albańczyków, którzy proklamowali „fałszywe państwo” na terytorium Serbii, zaś prezydent Serbii, zażądał od Sekretarza Generalnego ONZ natychmiastowego anulowania deklaracji niepodległości Kosowa, zapominając, że Organizacja takich kompetencji nie posiada. Problem ogłoszenia niepodległości przez Kosowo stał się jednak przedmiotem zainteresowania Zgromadzenia Ogólnego Narodów Zjednoczonych. 8 października 2008 roku 77 głosami ,za” przy 6 głosach ,przeciw” i 74 państwach wstrzymujących się od głosu (w tym Polska), podjęto decyzję o zwróceniu się do Międzynarodowego Trybunału Sprawiedliwości z prośbą o wydanie opinii doradczej w sprawie legalności ogłoszenia niepodległości przez Kosowo. Serbski minister spraw zagranicznych, Vuk Jeremić wskazał, że uzyskanie opinii trybunału zapobiegnie przekształceniu się kryzysu kosowskiego w ,głęboko problematyczny precedens w tych częściach świata, w których można obserwować secesjonistyczne ambicje" "11. Trzydzieści jeden państw (w tym Serbia) oraz autorzy jednostronnej deklaracji niepodległości wyrazili wolę uczestnictwa w części ustnej postępowania sądowego. Spośród państw członkowskich Unii Europejskiej przed trybunałem zjawili się przedstawiciele Austrii, Bułgarii, Cypru, Danii, Finlandii, Francji, Hiszpanii, Holandii, Niemiec i Wielkiej Brytanii. Na prezentację argumentów dla każdego państwa trybunał przeznaczył 45 minut. Do 1 marca 2010 roku MTS nie przedstawił opinii doradczej w omawianej sprawie.

Pomimo rozłamu, 4 lutego 2008 roku Unia Europejska przyjęła wspólne działanie 2008/123/WPZIB w sprawie ustanowienia Specjalnego Przedstawiciela w Kosowie z mandatem do 28 lutego 2009 roku, a następnie do 28 lutego 2010 roku. Funkcję tę objął Pieter Feith, który został zobowiązany między innymi do:

- wzmocnienia stabilności w regionie;

ziły również m.in. rządy Armenii, Azerbejdżanu, Białorusi, Boliwii, ChRL, Egiptu, Gruzji, Indii, Indonezji, Kazachstanu, Kirgistanu, Libii, Mołdawii, Singapuru, Sri Lanki, Tadżykistanu, Wenezueli i Wietnamu. Władze Chile, Iraku, Izraela, Jordanii (której władze dokonały jednak uznania Kosowa 8 lipca 2008 roku), Panamy, Stolicy Apostolskiej, Tajlandii, Ugandy i Uzbekistanu powstrzymały się od podjęcia decyzji w sprawie Kosowa, ogłaszając neutralne stanowisko wobec tej kwestii.

Backing Request by Serbia. General Assembly decides to seek International Court of Justice ruling on legality of Kosowo's independence, General Assembly GA/10764, 8.10.2008. 
- poszukiwania rozwiązań dotyczących przyszłego statusu Kosowa, który ma uwzględniać zasady demokracji, rządów prawa, stabilności i wieloetniczności;

- nadzór nad przestrzeganiem praw człowieka, w szczególności praw mniejszości;

- koordynowanie polityki UE wobec Kosowa ${ }^{12}$.

$\mathrm{W}$ dokumencie nie wspomniano jednak o fakcie ogłoszenia niepodległości przez Kosowo, nie poruszono również kwestii uznania nowego państwa, wiedząc, iż efektem byłoby odrzucenie projektu powołania Specjalnego Przedstawiciela.

Również 4 lutego 2008 roku Rada do spraw Ogólnych i Stosunków Zewnętrznych przyjęła wspólne działanie 2008/124/WPZiB w sprawie utworzenia Misji Unii Europejskiej - Rządy Prawa w Kosowie (tzw. EULEX), wyznaczając Yves de Kermabon'a na szefa misji. Do zadań EULEX, prowadzonej w ramach Europejskiej Polityki Bezpieczeństwa i Obrony, zaliczono doradztwo, monitorowanie i sprawowanie kontroli nad tworzeniem rządów prawa w Kosowie. Aktywność misji koncentruje się na trzech obszarach. Pierwszy dotyczy wzmocnienia policji i organów ścigania młodego państwa, drugi - organów wymiaru sprawiedliwości, zaś trzeci poświęcony jest kwestiom celnym. Celem jest bowiem stworzenie niezależnego i wielonarodowego systemu sądownictwa, policji i służb celnych. Misja, działająca od 9 grudnia 2008 roku, a mająca zakończyć funkcjonowanie 14 czerwca 2010 roku (zgodnie ze wspólnym działaniem 2009/445/WPZiB z 9 czerwca 2009 roku), współpracuje z organami wymiaru sprawiedliwości oraz instytucjami odpowiedzialnymi za egzekwowanie prawa. Jak podkreślił Javier Solana „Misja jest dowodem na silne zaangażowanie Unii Europejskiej na Zachodnich Bałkanach i przyczyni się do wzrostu stabilności w regionie"13. EULEX jest bowiem największą misją cywilną w historii Europejskiej Polityki Bezpieczeństwa i Obrony. Docelowo w skład misji wchodzić miało około 1900 funkcjonariuszy międzynarodowych (wśród nich: sędziowie, prokuratorzy, funkcjonariusze policji i służb celnych) i 1100 osobowy personel lokalny. Pełne zdolności operacyjne misja osiagnęła 6 kwietnia 2009 roku. Obecnie (stan na

12 Artykuł 2-3, Council Joint Action 2008/123/CFSP of 4 February 2008 appointing a European Special Representative in Kosovo, Official Journal L 42/88, 16.02.2008.

13 Javier Solana, UE High Representative for the CFSP, announces the start of EULEX Kosovo, Brussels, 5 December 2008, S 400/08, s. 1. 
koniec lutego 2010) tworzona jest przez blisko 1950 osobowy międzynarodowy personel oraz 1250 osobowy personel lokalny.

Podkreślić należy, że ustanowienie EULEX wzbudziło protesty strony serbskiej. Zdaniem premiera Serbii „Decyzją o wysłaniu misji EULEX [...] Unia Europejska dokonała zbrodni nad rezolucją nr 1244 [...], jasno gwarantującą poszanowanie integralności terytorialnej i całości Serbii [...], przekroiła uznane międzynarodowo granice Serbii",14.

18 lutego 2008 roku, na mocy decyzji 2008/213/WE ogłoszono Partnerstwo Unia Europejska-Kosowo. Uwzględniając jednak protesty władz Serbii podkreślono, iż jest ono częścią Partnerstwa z Serbią. W nazwie dokumentu pojawiło się stwierdzenie, że decyzja wskazuje zasady, priorytety i warunki Europejskiego Partnerstwa z Serbią, włączając Kosowo zgodnie z rezolucją RB ONZ nr 1244 z 10 czerwca 1999 roku. Stworzono więc swoistego rodzaju wirtualną rzeczywistość prawną, w której większość państw członkowskich UE uznaje Kosowo jako niepodległe państwo, godząc się jednocześnie na przyjmowanie rozwiązań prawnych wskazujących, iż Kosowo jest częścią Serbii. Za cel partnerstwa uznano określenie pól współpracy i przyjęcie ram zaangażowania finansowego w pomoc dla regionu. Na mocy partnerstwa, Kosowo zobowiązane zostało do podjęcia działań na rzecz „konstruktywnej współpracy” z Serbią i państwami sąsiednimi, współpracy z Międzynarodowym Trybunałem do spraw byłej Jugosławii (ICTY - ang. International Criminal Tribunal for the Former Yugoslavia), a także na rzecz wprowadzenia rządów prawa (z uwzględnieniem wieloetniczności i wolności religijnej), ochrony praw człowieka i mniejszości narodowych. Kluczowe znaczenie przypisano walce z przestępczością zorganizowaną (w szczególności z przestępczością finansową: korupcja, praniem brudnych pieniędzy; oraz nielegalnym handlem narkotykami i bronią), przeprowadzeniu reform administracji i sądownictwa. Częścią partnerstwa są również ustalenia gospodarcze. Zobowiązano władze Kosowa do wzmocnienia polityki fiskalnej i podatkowej, przeprowadzenia prywatyzacji, polepszenia kondycji finansowej przedsiębiorstw państwowych oraz do walki z bezrobociem. Zmiany w tym zakresie mają przyczynić się do wprowadzenia standardów euro-

${ }^{14}$ Ł. Kobeszko, Serbia - Kosowo. Belgrad nie chce rekompensaty ze niepodległość Kosowa, http://www.psz.pl. Cyt. za: M. Zobeniak, Kosowo - ramy zaangażowania UE w określenie przyszlego statusu, w: Wspólpraca - rywalizacja - walka. Studia przypadków z zakresu wspótczesnych stosunków międzynarodowych, red. A. Potyrała, Poznań 2008, s. 51. 
pejskich dotyczących zasad funkcjonowania wolnego rynku (swobodny przepływ towarów i kapitału). Podkreślono konieczność podjęcia działań na rzecz wzmocnienia systemu edukacji i nauki, poprawy ochrony środowiska naturalnego oraz wzmocnienia sektora rolnego i rybołówstwa. $\mathrm{Na}$ realizację założeń partnerstwa przeznaczono środki z Instrumentu Pomocy Przedakcesyjnej w wysokości ponad 199 milionów euro dla Kosowa w latach 2007-2010 (w okresie 2000-2006 Kosowo korzystało ze wsparcia finansowego wspólnie z Serbią i Czarnogórą, które wyniosło blisko 2 miliardy 560 milionów euro $)^{15}$. W lipcu 2008 roku zaakceptowano Plan Działania, określający etapy realizacji partnerstwa.

5 listopada 2008 roku Komisja Europejska przedstawiła komunikat w sprawie Strategii Rozszerzenia i Głównych Wyzwań 2008-2009, którego część stanowił raport w sprawie Kosowa. W raporcie nawiązano do proklamacji niepodległości Kosowa, wskazując, że „wytworzyła ona nową rzeczywistość" w Kosowie. Do zdania tego przychyliły się również Bank Światowy i Międzynarodowy Fundusz Walutowy, które 29 czerwca 2009 roku przyjęły Kosowo w poczet swoich członków.

\section{Stanowisko Unii Europejskiej wobec Osetii Południowej i Abchazji}

Najnowszym przypadkiem prowadzącym do napięć na arenie międzynarodowej jest ogłoszenie niepodległości przez Abchazję i Osetię Południową.

Do 1991 roku Abchazja stanowiła autonomiczną republikę w ramach Gruzińskiej SRR. W roku 1992 doszło do ogłoszenia secesji. W efekcie, w roku 1993 ustanowiono Misję Obserwacyjną NZ (tzw. UNOMIG - ang. United Nations Observatory Mission in Georgia), zaś od 1994 roku na obszarze Abchazji stacjonowały rosyjskie siły pokojowe w liczbie około 3 tysięcy osób. Pomimo międzynarodowych prób załagodzenia sytuacji i rozwiązania sporu (określenie przyszłego statusu Abchazji), 18 października 2006 roku parlament Abchazji zwrócił się do wspólnoty międzynarodowej z prośbą o wszczęcie procesu uznania Republiki Abchazji. W przypadku Osetii, do 1990 roku korzystała ze statusu obwodu autono-

15 Council Decision 2008/213/EC on the principles, priorities and conditions contained in the European Partnership with Serbia including Kosovo as defined by United Nations Security Council Resolution 1244 of 10 June 1999 and repealing Decision 2006/56/EC, 18.02.2008, Official Journal L 080, 19.03.2008. 
micznego Gruzińskiej SRR. W 1990 roku proklamowano powstanie Południowoosetyjskiej Radzieckiej Republiki Demokratycznej, co stało się przyczyną dwuletniego konfliktu z Gruzją. Na mocy porozumienia pokojowego, podpisanego w 1992 roku w Dagomysie przez przedstawicieli Gruzji i Rosji, na spornym obszarze rozmieszczono siły pokojowe. W tym samym roku, z inicjatywy KBWE/OBWE powołano komisję kontrolną przy udziale Gruzji, Federacji Rosyjskiej i przedstawicieli Osetii. 12 listopada 2006 roku w Osetii Południowej odbyło się referendum w sprawie przyszłego statusu. Jak przewidywano, referendum zakończyło się sukcesem zwolenników niepodległości - aż 99,88\% głosujących opowiedziało się za niepodległością.

W obu przypadkach społeczność międzynarodowa zgodnie odmówiła uznania. Dopiero konflikt rosyjsko-gruziński z sierpnia 2008 roku doprowadził do rozdźwięku na arenie międzynarodowej. Władze Rosji, Nikaragui oraz Wenezueli, powołując się na nową sytuację prawną, dokonały uznania dwóch, ich zdaniem, niepodległych państw: Abchazji i Osetii Południowej. Podstawą było stwierdzenie rosyjskiej Dumy z lutego 2008 roku, zgodnie z którym ,prawo narodów do samostanowienia nie może usprawiedliwiać niepodległości Kosowa, przy jednoczesnym odrzuceniu niepodległości innych państw samozwańczych, które uzyskały niepodległość faktyczną"16. Oczywistym jest, że decyzja Federacji Rosyjskiej o uznaniu dwóch nowych tworów państwowych, utworzonych w rejonie Kaukazu, była sposobem na odbudowanie wizerunku międzynarodowego, który ucierpiał w lutym 2008 roku, gdy władze Federacji Rosyjskiej nie potrafiły zapobiec międzynarodowemu uznaniu Kosowa. Uznanie stało się więc instrumentem gry politycznej, a zdaniem wielu - kolejnym aktem inicjującym nową zimną wojnę.

Decyzje o uznaniu Abchazji i Osetii Południowej spotkały się z natychmiastowym protestem rządu Gruzji, a także ostrym sprzeciwem innych państw. Ze stanowczym protestem wystapiła między innymi Unia Europejska. W oficjalnym stanowisku UE podkreślono, iż decyzja Rosji o uznaniu Osetii Południowej i Abchazji jest niemożliwa do zaakceptowania w świetle zasad niepodległości, suwerenności i integralności terytorialnej ${ }^{17}$. W konkluzjach przyjętych na spotkaniu Rady Unii Europejskiej

16 Cyt. za: N. Kulish, C. J. Chivers, Kosovo is Recognized but Rebuked by Others, „New York Times” 19.02.2008.

17 Extraordinary European Council, Presidency Conclusions, Brussels 1.09.2008, 12594/08, s. 2. 
we wrześniu 2008 roku, wskazano na konieczność rozwiązania problemu w oparciu o ,pełne poszanowanie zasad niepodległości, suwerenności i integralności terytorialnej”, wskazanych przez prawo międzynarodowe ${ }^{18}$.

Pomimo zdecydowanego sprzeciwu UE wobec aktu uznania Abchazji i Osetii Południowej, stanowczego charakteru nie maja jednak postanowienia planu Sarkozy-Miedwiediew ${ }^{19}$, wypracowane w sierpniu 2008 roku przez prezydencję francuską w imieniu UE. Tak zwany plan pokojowy przygotowano w celu doprowadzenia do zakończenia działań zbrojnych w Gruzji. Ustalono, iż strony powstrzymają się od dalszego użycia siły, zakończą wrogie działania i zapewnią swobodny dostęp dla pomocy humanitarnej. Jednocześnie jednak plan przewidywał wycofanie gruzińskich sił zbrojnych do baz, a sił rosyjskich - jedynie do linii sprzed wybuchu konfliktu. Dodatkowo, rosyjskim siłom zbrojnym plan przyznał prawo stosowania „dodatkowych środków bezpieczeństwa” (ang. additional security measures), nie precyzując tego terminu, co dało władzom rosyjskim pełną niemal dowolność interpretacyjną. Plan pokojowy przewidywał również rozpoczęcie międzynarodowych rozmów na temat bezpieczeństwa i stabilności w Abchazji i Osetii Południowej. Taki zapis odczytany został przez władze rosyjskie jako otwarcie drzwi do dyskusji nad przyszłym statusem tych obszarów, tym bardziej, że w dokumencie nie pojawiły się gwarancje integralności terytorialnej i suwerenności Gruzji. Na tym tle, nie należy również spodziewać się przełomu po działalności Specjalnego Przedstawiciela do spraw kryzysu gruzińskiego, powołanego 25 września 2008 roku na mocy wspólnego działania Rady. Stanowisko objął Pierre Morel, którego mandat wskazuje między innymi na pomoc w merytorycznym przygotowaniu stanowiska Unii Europejskiej, prezentowanego podczas międzynarodowych rozmów w celu wykonania postanowień Planu Sarkozy-Miedwiediew, a także na współpracę z Organizacją Narodów Zjednoczonych i Organizacją Bezpieczeństwa i Współpracy w Europie ${ }^{20}$. 15 września 2008 roku, w odpowiedzi na wezwanie rządu Gruzji, Rada przy-

18 Council of the European Union $2889^{\text {th }}$ Meeting, General Affairs and External Relations, Brussels, 15-16 September 2008, 13030/08 (Press 255), s. 8.

19 Na temat planu Sarkozy-Miedwiediew patrz: Council of the European Union Extraordinary Meeting, General Affairs and External Relations, Brussels, 13 August 2008, 12453/08 (Press 236), s. 6-7.

20 Por.: artykuł 3, Council Joint Action 2008/760/CFSP appointing the European Union Special Representative for the crisis in Georgia, 25.09.2008, Official Journal L 259/16, 27.09.2008. 
jęła wspólne działanie 2008/736/WPZiB w sprawie rozpoczęcia misji skierowanej na cywilne monitorowanie działań obu stron i implementacji planu Sarkozy-Miedwiediew. Zadaniem misji jest monitorowanie, analizowanie i raportowanie sytuacji związanej z procesem stabilizacji państwa, normalizacji rząów cywilnych, tworzenia społeczeństwa obywatelskiego, opartego o rządy i poszanowanie prawa. Dodatkowo, misja odpowiada za monitorowanie bezpieczeństwa połączeń transportowych, infrastruktury (m.in. obiektów energetycznych, obiektów użyteczności publicznej), a także nadzór nad powrotami uchodźców i uchodźców wewnętrznych.

Próby zaangażowania Unii Europejskiej oraz państw członkowskich w ustabilizowanie sytuacji w Gruzji widoczne były znaczenie wcześniej. 16 lipca 2004 roku działanie rozpoczęła Misja Rządów Prawa - EUJUST Themis, utworzona na mocy wspólnego działania 2004/523/WPZiB z 24 czerwca 2004 roku. Jej celem było wsparcie transformacji w Gruzji i pomoc w dostosowaniu prawa do europejskich standardów prawnych, walka z przestępczością, a także włączenie Gruzji do międzynarodowej współpracy sądowej w sprawach karnych. W skład misji o charakterze doradczym weszli prokuratorzy i sędziowie, udzielający pomocy w gruzińskim Ministerstwie Sprawiedliwości, Ministerstwie Spraw Wewnętrznych, Sądzie Najwyższym, biurze Prokuratora Generalnego. Misja zakończyła działanie 14 lipca 2005 roku. W 2005 roku Unia Europejska utworzyła Grupę Wsparcia Granic w Tbilisi, która zastąpiła Operację Monitorowania Granic OBWE. Zadaniem Grupy, tworzonej początkowo przez trzech, a następnie przez trzynastu ekspertów UE, jest stworzenie sprawnego systemu zarządzania granicami gruzińskimi. Zaangażowanie Unii Europejskiej w Gruzji przejawia się również w ustanowieniu 7 lipca 2003 roku Specjalnego Przedstawiciela UE dla Południowego Kaukazu, którego mandat obejmuje ,pomoc Armenii, Azerbejdżanowi i Gruzji w prowadzeniu reform politycznych i gospodarczych" oraz podejmowanie działań „na rzecz zapobiegania i rozwiązywania konfliktów w regionie"21.

Wielokrotnie Unia Europejska wskazywała na dążenie do uregulowania sytuacji w Gruzji w celu stworzenia ,państwa opartego o wartości i standardy, które mogą być bardziej atrakcyjne dla Południowej Osetii i Abchazji niż niepodległość lub bliższa integracja z Rosją"22. W tym celu,

21 Council Joint Action 2003/496/CFSP concerning the appointment of an EU Special Representative for the South Caucasus, 7.07.2003, Official Journal L 169/74, 8.07.2003.

22 Conflict Resolution in the South Caucasus: the EU's Role, International Crisis Report No. 173, International Crisis Group, Brussels, 20.03.2006, s. 11. 
a także w celu obniżenia stopnia zależności Abchazji i Osetii od wsparcia rosyjskiego, UE udzieliła finansowego wsparcia na rzecz rozwoju Gruzji, ze szczególnym uwzględnieniem tych dwóch rejonów. Między 1997 a 2006 rokiem na projekty pomocy humanitarnej i pomocy rozwojowej realizowane w Abchazji przeznaczono 25 milionów euro (wsparcie rolnictwa, systemu ochrony zdrowia, szkolnictwa), zaś w Osetii Południowej około 8 milionów euro (wsparcie systemu edukacji, rolnictwa, systemu transportu kolejowego). W latach 2007-2013, w ramach Instrumentu Europejskiej Polityki Sąsiedztwa, Gruzja otrzyma ponad 120 milionów euro, w tym 19 milionów na inicjatywy sprzyjające rozwiązaniu konfliktów wewnętrznych.

Pomimo ustanowienia instytucji odpowiedzialnych za stabilizowanie sytuacji w Gruzji, Unia Europejska nie podjęła trudu prowadzenia, ani nawet uczestnictwa w negocjacjach między zwaśnionymi stronami. Nie zaangażowała się w dyskusję nad przyczynami konfliktów wewnętrznych w Gruzji, czy nad stopniem odpowiedzialności za rozgrywające się wydarzenia. W procesie negocjacyjnym w Abchazji uczestniczyły jedynie trzy państwa członkowskie: Niemcy, Francja i Wielka Brytania, w oparciu o plan działania przyjęty przez Organizację Narodów Zjednoczonych. W Południowej Osetii, Komisja Europejska pełniła zaledwie funkcję obserwatora w rozmowach na temat odbudowy i rozwoju gospodarczego. W efekcie, 2 października 2007 roku, Peter Semneby, pełniący funkcję Specjalnego Przedstawiciela UE dla Południowego Kaukazu, w wystapieniu przed Komitetem ds. Zagranicznych Parlamentu Europejskiego przyznał, że „nie ma postępu w rozwiązywaniu konfliktów w Abchazji i Południowej Osetii”23.

Wskazane powyżej przykłady zaangażowania UE na rzecz uregulowania konfliktów w Gruzji, nie zapobiegły proklamowaniu niepodległości przez Abchazję i Osetię Południową, a także wybuchowi konfliktu między Gruzją i Rosją. Zaangażowanie było bowiem wielokierunkowe, ale powierzchowne. Obok braku precyzyjnie określonych celów europejskiej polityki w tym regionie (powiązanego z brakiem konkretnych żądań UE wobec stron konfliktu), powodem jest również przyjęcie, iż to Rosja jest najważniejszym graczem w rejonie Kaukazu. Unia Europejska nie podejmuje prób stworzenia przeciwwagi dla rosyjskich wpływów na tym obszarze, zaś początkowo sztywne stanowiska w kwestiach kaukaskich zawsze ulegają „,zmiękczeniu” pod wpływem Rosji. Priorytetem dla UE

23 No Progress in Georgia Conflict Resolution, 4.10.2007, http://europe.eu (15.02.2009). 
jest bowiem nie dążenie do stabilizacji w rejonie Kaukazu, lecz przede wszystkim zagwarantowanie przychylności i partnerstwa Rosji. Dodatkowo podkreślić należy, że Unia Europejska nie ma doświadczeń w rozwiązywaniu problemów państw, które nie są objęte polityką rozszerzenia ${ }^{24}$.

Próbą odpowiedzi na nową sytuację w Gruzji było zainicjowanie 7 maja 2009 roku Partnerstwa Wschodniego. Poza Gruzją, Partnerstwo objęło również Armenię, Azerbejdżan, Mołdawię, Ukrainę i warunkowo Białoruś. Założeniem jest stworzenie regionalnego forum współpracy, prowadzącej do ,przyspieszenia procesu stowarzyszenia politycznego i dalszej integracji gospodarczej" państw z Unią Europejską ${ }^{25}$. Partnerstwo Wschodnie skierowane jest na cztery obszary tematyczne. Pierwszym jest integracja gospodarcza, drugim - konwergencja z politykami sektorowymi Unii Europejskiej. Obszar trzeci dotyczy bezpieczeństwa energetycznego, zaś czwarty koncentruje się na kontaktach międzyludzkich. Realizacja założeń pierwszego obszaru opiera się o tworzenie ,pogłębionych i kompleksowych" stref wolnego handlu, pozwalających na liberalizację handlu i inwestycji. Wcielenie w życie założeń obszaru drugiego uzależniono od rozwoju instytucjonalnego, zbliżenia ustawodawstwa oraz jego dostosowania do wymogów prawa. Współpraca w ramach trzeciego obszaru partnerstwa koncentruje się na długoterminowych, stabilnych i bezpiecznych dostawach energii oraz stworzeniu swoistej współzależności energetycznej. Celem ostatniego obszaru partnerstwa jest wspieranie mobilności obywateli, realizowanie wspólnych projektów edukacyjnych, a także liberalizacja reżimu wizowego, prowadząca do zniesienia obowiązku wizowego. Na realizację założeń partnerstwa i wsparcie państw objętych tą inicjatywą przeznaczono kwotę $600 \mathrm{mi}$ lionów euro do 2013 roku.

\section{Przyczyny odmiennego podejścia}

Biorąc pod uwagę powyższe, nasuwa się pytanie: skoro większość państw członkowskich Unii Europejskiej dokonała uznania Kosowa jako

24 I. Chkhikvadze, To what extent could the European Neighbourhood Policy strengthen Georgian-Polish relations?, Fellowship Programme for Georgian Public Policy Analysts, Policy Paper 01/07, Warsaw 2007, s. 10.

25 Punkt 2, Wspólna deklaracja przyjęta podczas szczytu partnerstwa wschodniego $w$ Pradze, Praga, 7 maja 2009, 8435/09 (Presse 78). 
niepodległego państwa i pełnoprawnego członka społeczności międzynarodowej, dlaczego zatem odmówiono uznania Abchazji i Osetii Południowej? Zdaniem Olivera Ivanovića, serbskiego wiceministra do spraw Kosowa, stosowane są podwójne standardy, zaś państwa, które zdecydowały się na poparcie niepodległości Kosowa „szukają teraz gorączkowo argumentu, że był to wyjątkowy i niepowtarzalny przypadek"26.

Jak wspomniano na wstępie, 16 grudnia 1991 roku ministrowie spraw zagranicznych państw Wspólnot Europejskich przyjęli Deklarację w sprawie uznania nowych państw, powstałych w Europie Wschodniej i na obszarze Związku Radzieckiego. Pomimo wskazania warunków dokonania uznania, kontrowersje pozostały. $Z$ tego względu dla oceny legalności dokonania uznania, istotne znaczenie ma analiza warunków państwowości w prawie i stosunkach międzynarodowych. Zgodnie z definicją Georga Jellinka, państwo definiowane jest przez trzy elementy: terytorium, ludność i władzę. Z punktu widzenia prawa międzynarodowego jednak, elementy te nie są wystarczające dla zaistnienia państwa. Na mocy Konwencji o prawach i obowiązkach państw, przyjętej w Montevideo 26 grudnia 1933 roku, „Państwo, jako osoba prawa międzynarodowego, winno posiadać następujące atrybuty: a) stałą ludność, b) określone terytorium [niezależnie czy granice są ostatecznie ustalone - przyp. A.P.], c) rząd [niezależnie od składu czy charakteru rządu - przyp. A.P.] i d) zdolność do utrzymywania stosunków z innymi państwami”"27. Uwzględniając specyfikę współczesnych stosunków międzynarodowych oraz rolę, jaką odgrywają organizacje międzynarodowe, należy uznać, że ostatni element powinien być interpretowany jako zdolność utrzymywania kontaktów z innymi uczestnikami stosunków międzynarodowych, a nie jedynie z innymi państwami. Państwem jest jedynie twór zdolny do wchodzenia w interakcje międzynarodowe, a więc posiadający możliwość korzystania ze zdolności do czynności prawnych. Jedynie organizm zdolny potencjalnie do zawierania umów międzynarodowych, uczestnictwa w organizacjach międzynarodowych, nawiązywania i utrzymywania stosunków dyplomatycznych i konsularnych, wysuwania i dochodzenia roszczeń, do określenia obywatelstwa i przynależności państwowej, oraz ponoszący odpowiedzialność za swe międzynarodowe działania, może być przedmiotem uznania.

26 Cyt. za: Ł. Kobeszko, Wojna w Gruzji skutkiem secesji Kosowa, http://www.psz.pl (15.02.2009).

27 Artykuł 1, Konwencja o prawach i obowiazkach państw, Montevideo 1933, op. cit. 
Biorąc pod uwagę powyższe, stwierdzić należy, że kryteria te są spełnione w przypadku Kosowa, głównie z powodu wieloletniego zaangażowania społeczności międzynarodowej (poszczególnych państw, a także organizacji międzynarodowych, m.in. ONZ) w próby uregulowania sytuacji w Kosowie i przyznania temu obszarowi statusu międzynarodowego. W odniesieniu do Abchazji i Osetii Południowej nie można zaś mówić o zdolności do utrzymywania stosunków z innymi uczestnikami stosunków międzynarodowych.

Kluczowe znaczenie dla uznania państwa ma jednak zgoda społeczności międzynarodowej na przyznanie narodowi dążącemu do uzyskania państwowości, prawa do samostanowienia. To właśnie ten warunek jest powodem odmiennego podejścia państw Unii Europejskiej do problemu niepodległości Kosowa oraz Abchazji i Osetii Południowej.

Uwagę na szczególne prawa przysługujące narodom zwrócono podczas rewolucji francuskiej i amerykańskiej, podkreślając prawo narodu do decydowania o własnym losie. Proces wzrostu świadomości narodowej w drugiej połowie XIX wieku spowodował, iż zaczęto zwracać uwagę na zasadę samostanowienia narodów. W 1851 roku P. S. Mancini, profesor prawa międzynarodowego w swoim dziele zatytułowanym $O$ narodowości jako podstawie prawa międzynarodowego przedstawił idee praw przysługujących narodowi. Zdefiniował narodowość jako prawo do korzystania przez jednostki i zbiorowości z wolności. Wolność postrzegał zaś między innymi jako prawo do utworzenia własnego państwa, wyboru ustroju wewnętrznego oraz jako niezależność od innych narodów ${ }^{28}$. Odwołanie się do zasady samostanowienia narodów po zakończeniu I wojny światowej dało podstawy do zaakceptowania procesu tworzenia nowych państw na terytoriach należących do państw pokonanych. Prawo do samostanowienia traktowane jako zasada polityczna, a nie prawna, pozwoliło osiągnać doraźne cele polityczne. Rzecznikiem uznania prawa narodów do samostanowienia za zasadę prawa międzynarodowego był amerykański prezydent W. Wilson. W licznych wystapieniach wskazywał, że każda władza wywodzi swe uprawnienia z woli rządzonych, a każdy naród ma prawo wyboru władzy, której będzie podlegał. W przemówieniu z 11 lutego 1918 roku W. Wilson stwierdził, że aspiracje naro-

28 L. Dembiński, Samostanowienie $w$ prawie i praktyce ONZ, Warszawa 1969, s. 12. Dzieło P. S. Manciniego funkcjonuje w polskiej nauce prawa międzynarodowego również pod tytułem Narodowość jako źródło prawa międzynarodowego. Patrz: R. Bierzanek, J. Symonides, op. cit., s. 52. 
dowe muszą być uwzględniane, zaś zasada samostanowienia powinna być normą działania na arenie międzynarodowej. Podczas konferencji pokojowej w Wersalu W. Wilson podkreślił, iż podstawową zasadą obowiązującą w powojennym świecie powinna być zasada, zgodnie z którą żaden rząd lub grupa rządów nie ma prawa wymuszania posłuszeństwa od wolnych narodów ${ }^{29}$. Postulował, aby w artykule 10 projektu Paktu Ligi Narodów umieścić prawo narodów do samostanowienia. Artykuł $10 \mathrm{w}$ proponowanym brzmieniu, gwarantując niezależność polityczną i integralność terytorialną państw, dopuszczał jednocześnie możliwość dokonania przekształceń terytorialnych w celu realizacji zasady samostanowienia. Ewentualne przekształcenia terytorialne byłyby efektem zmian stosunków rasowych, społecznych lub politycznych zachodzących wśród ludności zamieszkującej te tereny i powodujących wzrost niepodległościowych aspiracji wśród ludności. Do zmian terytorialnych dochodziłoby również za zgodą 3/4 delegatów Ligi Narodów działających w imieniu i na rzecz zainteresowanej ludności ${ }^{30}$. Postulat ten nie zyskał jednak międzynarodowego poparcia. W Pakcie Ligi Narodów wskazano, iż prawo do samostanowienia może urzeczywistniać się jedynie przez przyznanie narodom autonomii w ramach państwa ${ }^{31}$, nie zaś przez uznanie prawa narodów do swobodnego określenia swego statusu politycznego. W okresie międzywojennym prawo do samostanowienia funkcjonowało więc jako zasada polityczna. Opinia doradcza Komitetu Prawników Ligi Narodów w sprawie wysp Alandzkich z roku 1921 potwierdziła, iż samostanowienie jest wyłącznie koncepcją polityczna, a nie zasadą prawa międzynarodowego $^{32}$. Zasada samostanowienia po raz pierwszy znalazła swe odbicie w prawie międzynarodowym dopiero po zakończeniu drugiej wojny światowej. Karta Atlantycka podpisana w sierpniu 1941 roku nie wymieniała zasady samostanowienia w sposób wyraźny, lecz odwoływała się do niej stwierdzając, że sygnatariusze Karty „,nie zgodzą się na żadne zmiany te-

29 H. S. Johnson, Self-Determination within the Community of Nations, Leyden 1967, s. 33.

${ }^{30}$ M. Pomerance, Self-Determination in Law and Practice. The New Doctrine in the United Nations, The Hague-Boston-London 1982, s. 7.

31 L. Dembiński, op. cit., s. 17.

32 Szerzej: J. Tyranowski, Integralność terytorialna, nienaruszalność granic i samostanowienie w prawie międzynarodowym, Warszawa-Poznań 1990, s. 187-188, oraz Ö. Österud, Sovereign Statehood and National Self-Determination. A World Order Dilemma, w: Subduing sovereignty. Sovereignty and the right to intervene, ed. M. Heiberg, London 1994, s. 23. 
rytorialne, które by nie odpowiadały swobodnie wyrażonym życzeniom ludów zainteresowanych” oraz że ,szanują oni prawo wszystkich ludów do wybrania sobie formy rządu, pod jakim chcą żyć, i pragną oni, żeby przywrócono prawa suwerenne i autonomię tym, którym je odebrano siłą" ${ }^{33}$. Pierwszym dokumentem międzynarodowym, w którym zasada samostanowienia została wymieniona expressis verbis jest Karta Narodów Zjednoczonych. W artykule 1(2) stwierdzono, iż przyjazne stosunki między państwami powinny być rozwijane przy poszanowaniu zasady równouprawnienia i samostanowienia narodów. Podkreślono, że tylko poszanowanie zasady równouprawnienia i samostanowienia narodów pozwoli na stworzenie warunków stabilizacji i dobrobytu koniecznych do utrzymania pokojowych i przyjaznych stosunków między narodami (artykuł 55). Zdefiniowanie zasady samostanowienia nastąpiło 14 grudnia 1960 roku w Deklaracji w sprawie przyznania niepodległości krajom i narodom kolonialnym (rezolucja nr 1514 XV). Podkreślając nieuchronność procesu dekolonizacji zagwarantowano prawo narodów do samostanowienia. Samostanowienie zdefiniowano jako prawo do swobodnego określenia statusu politycznego i swobodnego zapewnienia rozwoju ekonomicznego, społecznego i kulturalnego. Prawo do samostanowienia przysługuje, zgodnie z punktem 3 deklaracji, niezależnie od stopnia rozwoju politycznego, ekonomicznego, socjalnego czy edukacyjnego narodu. 15 grudnia 1960 roku uchwalono rezolucję nr 1541 (XV), w której określono sposoby korzystania z prawa do samostanowienia. W myśl postanowień rezolucji, korzystając $\mathrm{z}$ prawa do samostanowienia naród może utworzyć własne niepodległe państwo, stowarzyszyć się z państwem już istniejącym lub zadecydować o integracji z innym państwem. W każdym przypadku decyzja o przyszłym statusie politycznym powinna być rezultatem podjętej swobodnie i dobrowolnie woli ludności, zamieszkującej określone terytorium, woli wyrażonej w demokratyczny sposób ${ }^{34}$.

$\mathrm{W}$ tak zdefiniowanym prawie do samostanowienia uwage zwracają dwa aspekty. W aspekcie wewnętrznym prawo do samostanowienia rozu-

33 Artykuł 2 i 3, Karta Atlantycka, 1941, w: Wybór dokumentów do nauki prawa międzynarodowego, oprac. K. Kocot, K. Wolfke, Wrocław-Warszawa 1976.

34 Na temat prawnomiędzynarodowego rozwoju prawa do samostanowienia patrz: A. Potyrała, Prawo do samostanowienia a problem suwerenności państwa, w: Zbrojne konflikty i spory międzynarodowe u progu XXI wieku. Analiza problemów i studia przypadków, red. W. Malendowski, Wrocław 2003, s. 76-80. Szerzej: M Perkowski, Samostanowienie narodów w prawie międzynarodowym, Warszawa 2001. 
miane jest jako możność określenia formy rządu, w aspekcie zewnętrznym oznacza uprawnienie narodu do swobodnego określenia statusu politycznego. Najwięcej kontrowersji wzbudziło stwierdzenie dotyczące swobodnego określenia statusu politycznego. Zgodnie z rezolucją nr 1541 (XV) określenie statusu politycznego nastąpić może na trzy sposoby. Naród powołujący się na prawo do samostanowienia może zadecydować o: utworzeniu własnego, niepodległego państwa; stowarzyszeniu się z istniejącym państwem; lub oderwaniu się od istniejącego państwa i integracji z innym państwem. Te trzy sposoby realizacji prawa do samostanowienia w odniesieniu do narodów kolonialnych nie budziły poważniejszych zastrzeżeń. Odniesienie ich do wszystkich narodów stanowiło jednak zagrożenie państwowej suwerenności i porządku międzynarodowego. Społeczność międzynarodowa zwróciła uwagę, że prawo do samostanowienia jako prawo uniwersalne doprowadzić może do nasilenia ruchów separatystycznych wśród narodów powołujących się na prawo do samostanowienia. Z tego względu w Deklaracji zasad prawa międzynarodowego z 1970 roku podkreślono, że prawo narodów do samostanowienia nie może być rozumiane jako „upoważnienie lub zachęta do podjęcia jakiegokolwiek działania, które prowadziłoby do rozbicia lub naruszenia, całkowicie lub częściowo, integralności terytorialnej lub jedności politycznej suwerennych i niepodległych państw, które postępują zgodnie z zasadą równouprawnienia i samostanowienia narodów"35. Stwierdzono, iż prawo do samostanowienia może być definiowane wyłącznie jako uprawnienie do domagania się oraz rozwijania autonomii w ramach istniejącego państwa, terytorium którego zamieszkuje grupa narodowa. Uznano, iż naród nie może powoływać się na prawo do samostanowienia wysuwając żądania niepodległościowe, jeżeli państwo postępuje zgodnie z zasadą równouprawnienia oraz samostanowienia narodów. Jednoznacznie odrzucona została więc interpretacja prawa do samostanowienia jako prawa do secesji grup narodowych spod władzy istniejących państw. Secesja jest dopuszczalna jedynie w przypadku poważnych i masowych naruszeń praw człowieka.

Odnosząc powyższe kryteria i warunki do sytuacji Kosowa, Abchazji i Osetii Południowej, można odnaleźć uzasadnienie dla odmiennego podejścia Unii Europejskiej wobec tych trzech sytuacji. W przypadku Kosowa,

35 Deklaracja zasad prawa międzynarodowego dotyczacych przyjaznych stosunków i współdziałania państw zgodnie z Karta Narodów Zjednoczonych (24.10.1970), w: Wybór dokumentów, op. cit. 
wielokrotnie dochodziło do naruszania praw i wolności osób zamieszkujących Kosowo (co doprowadziło nawet do zbrojnej interwencji państw Sojuszu Północnoatlantyckiego w 1999 roku), zaś władze najpierw Jugosławii, potem Serbii i Czarnogóry, a następnie Serbii nie respektowały prawa do rozwijania autonomii. W sytuacji, gdy państwo nie zapewnia możliwości rozwoju grupy narodowej, grupa ta może skorzystać z samostanowienia rozumianego jako prawo do secesji i utworzenia niepodległego państwa. W przypadku mieszkańców Abchazji i Osetii Południowej natomiast, zachowano wszelkie gwarancje autonomii, przyznając prawo do jej rozwijania w ramach państwa gruzińskiego.

Poza wskazanymi kryteriami prawnymi, odnoszącymi się do warunków zaistnienia państwowości oraz korzystania z prawa do samostanowienia, pod uwagę równie często bierze się kryteria polityczne. Decyzje w sprawie Kosowa, Abchazji i Osetii Południowej podejmowane były także w oparciu o czynniki natury subiektywnej. Zaliczyć do nich można między innymi położenie geograficzne, mierzone odległością od Brukseli, interesy polityczne i gospodarcze Unii Europejskiej w danym regionie (dążenie do stowarzyszenia, a nawet członkostwa w Unii Europejskiej), a także chęć udowodnienia, że interwencja zbrojna z 1999 roku na rzecz poszanowania praw kosowskich Albańczyków była koniecznością. W przypadku Abchazji i Osetii Południowej rolę odgrywa także dążenie do osłabienia pozycji Rosji w regionie.

$$
* * *
$$

Sytuacja, w której społeczność międzynarodowa nie jest w stanie wypracować wspólnego stanowiska względem nowego bytu państwowego, prowadzi do negatywnych konsekwencji. W przypadku niejednolitego stanowiska państw członkowskich Unii Europejskiej wobec Kosowa, osłabieniu ulega prestiż i siła oddziaływania Unii na arenie międzynarodowej. W odniesieniu do problemu Abchazji i Osetii Południowej natomiast, działania UE obrazuja, że samo wyrażenie zainteresowania określonym problemem oraz udzielanie 'apolitycznej' pomocy finansowej, którym nie towarzyszą wyraźnie i precyzyjnie zdefiniowane cele polityczne (np. żądania zawieszenia wrogich działań, czy zawarcia pokoju), działalność instytucji wyposażonych w silny mandat oraz proces aktywnych negocjacji, nie przyczynia się do rozwiązania palącego problemu międzynarodowego, narażając na szwank pozycję międzynarodową Unii Europejskiej. 
Po raz kolejny państwa członkowskie pokazują, iż koncepcja Wspólnej Polityki Zagranicznej i Bezpieczeństwa, wspierana między innymi przez Europejską Politykę Sąsiedztwa, jest pozbawiona stabilnych podstaw. Rozbieżności między państwami członkowskimi powodują, że nadal mówić można o 27 odrębnych politykach zagranicznych, zaś WPZiB w wielu przypadkach (m.in. interwencji w Iraku w 2003 roku) jest tworem czysto teoretycznym i przykładem myślenia życzeniowego.

\section{Summary}

When the European Union member states' attitude to Kosovo is not uniform, the EU's prestige and influence on the international arena deteriorates. As far as the issue of Abkhazia and South Ossetia is concerned, the EU's activities show that mere expressions of interest in the matter and providing 'apolitical' financial aid does not contribute to solving this thorny international problem, and undermines the international position of the European Union unless it is coupled with clear and precise political aims, the operations of institutions with a strong mandate or a process of active negotiation. Once more, member states show that the concept of the Common Foreign and Security Policy, supported among others by the European Neighborhood Policy, does not have firm foundations. 